\title{
Classroom Physical Environment and Academic Achievement of Students
}

\author{
Swati H. Kekare ${ }^{1}$
}

\begin{abstract}
:
The present study explored the relationship between classroom environment and academic achievement of the subjects. The subjects 11th class students. The sample of 80 students was selected from various colleges of Aurangabad city. Simple random sampling method was used for selecting subjects. The study was experimental "pre-test post-test equivalent group design" was used for this study. Statistical data was collected from pre-test post-test. Mean, standard deviation and test were used for statistical procedure. In this study results are significant at 0.05 level. The study showed that there is significant difference between classroom physical environment and academic achievement of subjects.
\end{abstract}

Keywords: Classroom physical environment, academic achievement, 11th class students.

Schools and colleges are the most important part of student's life, they spend $1 / 4$ of the day (6hours) in the schools and colleges. The classroom is the formal environment for the learning. A comfortable and conductive classroom environment motivates the students to perform better and encourage the learning process. There are so many factors which influence the students' whole school performance. Classroom physical environment is the most important variable.

Student's academic achievement is influenced by school environment. Classroom physical environment plays important role in student's educational success. Physical environment defined as the physical characteristics of classroom. Physical classroom environment includes different things like size of classroom, floor, walls, desks, lighting, school structure, school climate, computer etc. Many studies found that physical environment is essential for educational success. Studies in Capistrano, United School, District in Orange city, California, found that the students in well-designed classrooms performed 19 to $26 \%$ better than their peers in classrooms without these features (Hale 2002). Kaur A. (2001), Bennu (2002) shows that there is a positive correlation between classroom environment and academic achievement. Temperature and ventilation also affected the classroom learning environment.

${ }^{1}$ Department of Psychology, Milind college of Arts, Aurangabad.

(C) 2015 I S Kekare; licensee IJIP. This is an Open Access Research distributed under the terms of the Creative Commons Attribution License (http://creativecommons.org/licenses/by/2.0), which permits unrestricted use, distribution, and reproduction in any Medium, provided the original work is properly cited. 
In too cold and too hot classrooms students feel uncomfortable. According to Halstead 1974, high temperature and humidity creates physiological and psychological problems and people work more slowly apply much efforts and causes make more mistakes and errors.

The research done by Treagust and Wahyudi (2004), found that there were significant difference between perception of preferred and actual learning environment, with students tending to prefer more favourable classroom environment than which they actually experienced. Lyons(2001) found in his study that poor school facilities impact theteacher's performance and has negative effects on student's achievement. In the study MacAulay(1990) and Walker (1995), found that well-structured classrooms improve student's academic achievement.

\section{AIM OF THE STUDY}

Classroom physical environment plays important role in academic achievement of student. The present study indents to examine the effect of classroom physical environment on student's academic achievement.

\section{OBJECTIVES OF THE STUDY}

1. To find out the relationship between classroom physical environment and academic achievement of the subjects.

\section{HYPOTHESES}

1. There is no significant difference between performance of experimental and control groups on pre-test.

2. There is significance difference between performance of experimental group and control group on post-test.

\section{METHODOLOGY}

Sample:

For this study 80 subjects were selected from different colleges of Aurangabad city. The subjects were 11th class students. Male and female ratio will be taken in equal sample size. For this study random sampling method was used.

\section{Tools:}

For this study pre-test post-test method was used for data collection. Two question papers were prepared for pre-test and post-test and used as research instruments. The scores on pre-test and post-test were used for statistical analysis.

\section{Variables under study:}

Independent variable

1. Classroom physical environment

Dependent variable

1. Academic achievement 


\section{Classroom Physical Environment and Academic Achievement of Students}

\section{Design of the study:}

This study was experimental study. The pre-test post-test equivalent groups were used. Sample subjects were randomly allocated to experimental group and control group.

Research design

\begin{tabular}{|l|l|l|l|}
\hline Group & Pre-test & $\begin{array}{l}\text { Independent } \\
\text { Variable }\end{array}$ & Post-test \\
\hline E & $\mathrm{Y}_{\mathrm{b}}$ & $\mathrm{X}$ & $\mathrm{Y}_{\mathrm{a}}$ \\
\hline $\mathrm{C}$ & $\mathrm{Y}_{\mathrm{b}}$ & - & $\mathrm{Y}_{\mathrm{a}}$ \\
\hline
\end{tabular}

E - Experimental Group

C - Control Group

$\mathrm{Y}_{\mathrm{b}}$ - pre-test score

$\mathrm{Y}_{\mathrm{a}}$ - post-test score

\section{Procedure}

80 students were selected randomly from different colleges from Aurangabad city. Subjects were randomly allocated to experimental group and control group. For this study two teachers were appointed for teach English subject. They were taught for two weeks. They had taught four lessons. They prepared two question papers. One was used for pre-test and second was used for post-test and the marks on these two question papers were used as a scores on pre-test and posttest. In this way statistical data was collected through pre-test and post-test technique.

\section{Selection of the teachers for the experiment}

For this study two teachers which have same qualification and same teaching experience were selected for both groups. Their qualification were M.A. English and B.Ed

\section{Arrangement of classroom physical environment for this study}

The researcher arranged two classrooms for this study one for experimental group and second for control group. The classroom for experimental group had various physical facilities proper deskchairs arrangement, proper lighting, ventilation, harts, projector, whiteboard, well painted walls, drinking water etc. Classroom was specious. The classroom for control group had only black board, benches and classroom was very small.

\section{RESULT AND DISCUSSION}

Ho. 1 There is no significant difference between performance of experimental and control groups on pre-test.

Table 1: Showing the significance of difference between the mean scores of control and experimental groups on pre-test.

\begin{tabular}{|l|c|c|c|c|c|}
\hline Category & $\mathrm{N}$ & Mean & SD & SE & T \\
\hline Experimental Group & 40 & 23.07 & 3.38 & 0.8 & 0.83 \\
\cline { 1 - 4 } Control Group & 40 & 40.55 & 4.05 & & \\
\hline
\end{tabular}

Non-significant $(\mathrm{p}<0.05) \mathrm{df}-79 \mathrm{t}$ at 0.05 level $=0.83$ 


\section{Classroom Physical Environment and Academic Achievement of Students}

The mean score of experimental group and control group on pre-test are 23.07 and 40.55 Standard deviation for experimental and control group are 3.38 and 4.05 . The ' $t$ ' ratio is 0.83 which is non-significant at 0.05 level. So the null hypothesis "there is no significant difference between the performance of control and experimental groups on pre-test" is accepted. It is concluded that the performance of students of experimental group and control group are similar on pre-test.

Ho. 2 There is no significant difference between the performance of experimental and control groups on post-test.

Table 2. Showing the significance of difference between the mean scores of control and experimental groups on post-test.

\begin{tabular}{|l|c|c|c|c|c|}
\hline Category & $\mathrm{N}$ & Mean & SD & SE & T \\
\hline Experimental Group & 40 & 40.55 & 4.05 & 4.12 & 2.80 \\
\cline { 1 - 4 } Control Group & 40 & 29 & 4.97 & & \\
\hline
\end{tabular}

Significant $(\mathrm{p}<0.05) \quad \mathrm{t}$ at 0.05 level $=2.80$

The mean score of experimental group and control group on post-test are 40.55 and 29. Standard deviation for experimental and control groups are 4.05 and 4.97. $\mathrm{t}$ ratio is 2.80 which is significant at 0.05 level. Hence null hypothesis that "there is no significant difference between the performance of experimental group and control group on post-test" is rejected. Hence it was concluded that subjects of experimental group performed better as compared to the subjects of control group on post-test.

\section{DISCUSSION}

The present study discovered relationship between academic achievement and classroom environment. This was an experimental study. For this study researcher is used pre-test post-test equivalent group design. For this study subjects are divided into two groups. Two classrooms are arranged for this experiment. Classroom for experimental group has given various physical facilities i.e. benches, whiteboard, drinking water, projector, ventilation, lighting etc.an this classroom was specious. Classroom for control group has not given these facilities, they had only blackboard, benches, and this classroom was very small. At first researcher has taken pre-test. Both groups are taught by two teachers. This experiment is continued for two weeks. After completion researcher administered post-test immediately. In this way data was collected.

Table I shows that there is no significant difference between the performance of control and experimental groups on pre-test calculated ' $t$ ' value was found 0.83 , which is less than table value of ' $t$ ' at 0.05 level. So the null hypothesis that there is no significant difference between the performance of control and experimental groups on pre-test is accepted. These results showed that the subjects of experimental group and control group performed similar on pre-test.

Table II shows that the subjects those has given physical classroom environment (experimental group) performed better compare to the subjects those had not given physical classroom 


\section{Classroom Physical Environment and Academic Achievement of Students}

environment (control group). In this investigation calculated ' $t$ ' value was found 2.80 which is more than table value of 't' at 0.05 level. So the null hypothesis that "there is no significant difference between the performance of experimental group and control group on post-test" is rejected. Hence it was concluded that subjects of experimental group performed better as compare to the student of control group on post-test.

\section{CONCLUSION:}

1. There is no significant difference between the performance of experimental group and control group on pre-test.

2. There is significant difference between classroom physical environment and academic achievement of the subject. If students given well-furnished classroom with various facilities, there learning performance will increase.

\section{REFERENCES:}

Haertel F.D., Walberg. H.J., \& Haertel E.H. (1981) Socio-psychological environment and learning: A Quantitive synthesis. British Education Research Journal 7, 27-36.

Quiser Suleman., Hassan Dania Aslam., Ishtiap Hussain, (2014) Effect of classroom Physical Environment on the academic achievement score of Secondary School Students in Kohat Division, International Journal of Learning and Development, Vol. 4, No-1, 7182.

Radhey Shyam., and Rajendra Shrimali (2011). A study of relation between school environment and academic achievement of gifted children, International Journal of Research in Social Sciences and Humanities, Vol. No. 1, Issue No. II, oct-dec.

Oredien, A. O., \& Oloyede, D.O. (2007). Supervision and quality of Teaching personal effect on student academic performance, Educational Research and Review, 2(3), 032-035.

Daniel K. Korir,\& Felix Kipkemboi (2014). The impact of school environment and peer influences on subject's academic performance in Vihiga Country, Kenya.International Journal of Humanities and Social Sciences Vol. 4 5(1). 240-251.

Hilary Coon, Gregory Carey., David W. Fulker, \& J.C. Defries (1993). Influences of school environment on the academic achievement scores of adopted and nonadoptedchildren.Intelligence 17,79-104.

Rutter M. (1983). School effect on pupil progress: research findings and policy implication. Child Development, 54, 1-29.

Benipal A. S., Jaspal Singh (2014). A study of Academic Achievement of adolescents in relation to their perception of classroom environment in Punjab., Educationia Confab, Vol. 3, No. $7,18-26$ 